\title{
Exploring the scope of and gaps in the teaching and learning of Business Studies at school and teacher education levels
}

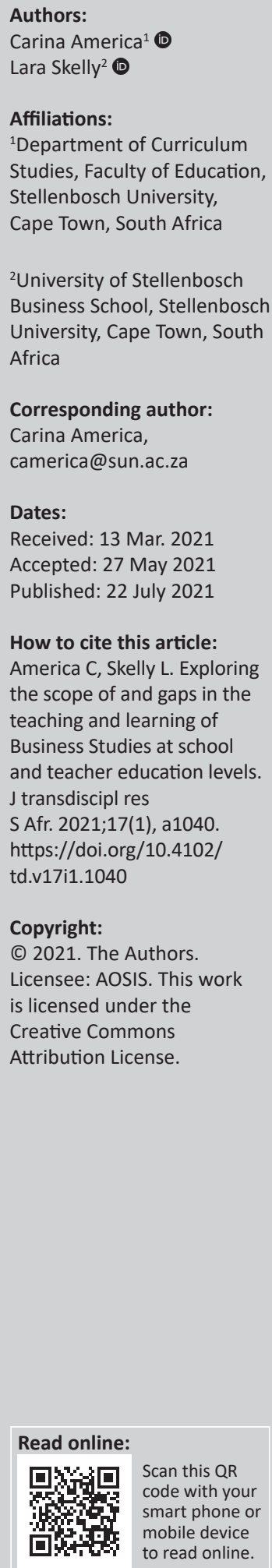

\begin{abstract}
The relevance of Business Studies Education (BSE) at school and in higher education is undisputed, given the rising levels of youth unemployment and the need for an appropriate skill set for potential entrepreneurs. Although a relatively large corpus of general business education literature is available, the same does not necessarily apply to published research related specifically to business studies teaching and learning at school and in teacher education. The aim of this research was to explore the scope, similarities, differences and potential gaps in the teaching and learning of Business Studies within school and teacher education contexts. A meta-study methodology was applied in this study to provide a comprehensive review and synthesis of peer-reviewed research publications in business studies education. An overview of the challenges facing BSE within the South African context is provided. A framework encompassing situational, pedagogical, practical and disciplinary knowledge areas guided the analytical overview to underscore the limitations and particular points of focus of current and past research. In addition, the meta-study set out to establish the scope, similarities and differences of promising areas for future research. Findings suggest that BSE research remains limited, entrepreneurship is an important focus for research and that not enough research has been conducted about situational knowledge. Recommendations include the need to analyse the complexities of teacher education and training, to investigate and critique the theoretical foundations of business studies education and to evaluate the shifts in school curriculum policy, development and design.
\end{abstract}

Keywords: business studies; teacher education; meta-study; content knowledge; situational knowledge; practical knowledge; pedagogical knowledge.

\section{Introduction}

Business education at school level (SL) is often geared towards the acquisition of knowledge and skills for potential employability, enterprise capability and responsible citizenship. ${ }^{1}$ Learners make career and prospective study choices based on the subjects they study at SL, signalling the crucial role an education system plays. ${ }^{2,3}$ Business Studies is an ideal school subject that could help prepare young people to make sense of the fast-paced business and technological advancements in the world of work. However, the subject is facing some challenges, such as its perceived low status in comparison to other established subjects ${ }^{1}$ and the limited research conducted in the field within the contexts of school and teacher education (TE).

Quite a large corpus of general business education literature is available, but it is difficult to establish the scope of research on Business Studies Education (BSE). Business studies education refers to the teaching and learning of business knowledge at SL and in TE. The question arises as follows: how can BSE best practices based on existing literature provide guidance to business teacher educators, practitioners and researchers? Of greater concern is that the depth and breadth of the research undertaken on BSE in South Africa are relatively unknown. The aim of this article was to examine the similarities and differences in existing research studies to identify the knowledge gaps in the literature on business studies teaching and learning. Identifying these gaps could be a catalyst to develop practice and research guidelines for the future.

Business Studies is regarded as a theoretical subject because it has a well-established body of content knowledge. The subject matter content knowledge is what Young et al. ${ }^{4}$ refer to as powerful (specialised) knowledge, which is reliable, and which should be prioritised in the curriculum. The acquisition of powerful knowledge presents an opportunity for learners to excel 
beyond their everyday lives. Hordern 5 advises that the pedagogical challenge is to make powerful knowledge relevant to all learners from all backgrounds. Business Studies also incorporates a vocational component because it is perceived as a preparation for employment in business, although this view is less prevalent in South Africa. In some instances, pedagogical shifts are needed, which entail adjusting to the context and the diversity of learners where learning takes place. The teaching and learning process therefore requires a combination of knowledge areas, such as discipline-specific knowledge, knowledge about pedagogy and the curriculum, knowledge about the learners and their context and practical knowledge. These four knowledge areas are included in the Minimum Requirements for Teacher Education Qualification (MRTEQ) as important learning areas for TE, which are then cascaded down to the school context. ${ }^{6}$ These knowledge areas consequently underpin the thematic analysis in this meta-study.

This article presents the findings from a meta-study of the scope of research conducted in BSE from 1994 to 2015 as it relates to pre-service and in-service teaching and learning in South Africa. Pre-service teaching and learning refer to the TE context and in-service refers to the school context where teaching and learning take place.

\section{Literature review and background of the study}

Business education was founded based on its relevance to the business world and its usefulness to students in terms of its real-life application. ${ }^{7}$ Business knowledge not only became increasingly important as corporations competed in the global arena, but also became important in the handling of personal finances and making informed decisions as consumers. Fierce competitiveness led to the adoption of an underlying principle that business curricula should be developed based on what employers (businesses) wanted, and to a lesser degree on what is beneficial for society or the environment. Stronach ${ }^{8}$ argues that the business education curricula rarely show educational relevance in terms of its teaching and (vocational) learning. Instead, it generally has a focus on instrumentality within a particular economic model or paradigm. There has been ongoing critique of the value of business education and the trends and limitations of research conducted in the field. Whilst the value of business knowledge at SL is acknowledged, ${ }^{1,2,3}$ the research conducted in school and TE contexts remains inadequate.

Business education within a South African school context includes subjects such as Economic and Management Sciences (grades 7-9) and Business Studies, Economics and Accounting in the further education and training (FET) phase (grades 1012). Business Studies therefore takes place at high school and TE institutions, with the focus on the teaching and learning of the theory and practice, and of business principles that, for example, underpin the development of entrepreneurial initiatives, sustainable enterprises and economic growth. ${ }^{9}$ According to the Curriculum Assessment and Policy
Statement (CAPS) ${ }^{9}$ for Business Studies in the FET phase, the subject 'deals with the knowledge, skills, attitudes, and values critical for informed, productive, ethical and responsible participation in the formal and informal economic sectors' (p. 8). Since 1994, there were several curriculum restructuring processes to address the ills of an unequal apartheid education system. In the South African context, we refer to a learner as someone who is enrolled at a school and a student who is enrolled at a higher education institution - this distinction is adhered to in this article. With the inception of CAPS in 2012, an increased level of rigour and critical understanding of the subject matter was required from a learner and studentteacher perspective. ${ }^{10}$ Moreover, a change in pedagogical content knowledge was required to reflect changing contexts and practices. Business Studies knowledge is mostly theoretical; however, an active learning pedagogy is almost imperative to heighten social responsibility, 'real-world' relevance and the acquisition of an adaptable skill set for a fast-changing (technological) business environment. ${ }^{11}$ Alsagheer et al. ${ }^{12}$ are of the view that BSE is not as widespread globally and does not get so much attention in the literature. America and Le Grange ${ }^{13}$ also point out that there has been limited research on the training of business education teachers at higher education levels. They argue that because TE is a field that functions at the interface of higher education and schooling, the complexity and context of the school system (in)directly affect TE programmes. We discuss some of these complexities briefly here.

Firstly, business education curriculum policies are often devoid of any substantive philosophical grounding. ${ }^{7}$ Besides, any semblance of the underlying philosophy of business education is usually justified based on the functional needs of the business and the ultimate vision of economic growth for the country. Fisher ${ }^{7}$ argues that the conceptual basis and theoretical framework of business education do not essentially rely on the educative value of the development of the person who studies business phenomena. Furthermore, a curriculum is generally the mouthpiece of a government's sociopolitical and economic goals; therefore, teaching and learning are normally aligned to such goals. Maistry et al. ${ }^{14}$ are of the opinion that business education has shown an ideological bias, which is couched within a predominant neoclassical economic world view that is mostly unrelated to local (South) African realities. Moreover, BSE is underpinned by a predominant theory of productivity and competitiveness and does not really reflect a theoretical basis that integrates educational theories. Critical reflection why production takes place and how it affects the various stakeholders (including society $)^{8}$ are still relevant today and, as purported by America, ${ }^{15,16}$ are particularly appropriate in BSE at SL. Yet, there is limited research on pedagogy and critical reflexive teaching in BSE.

Secondly, the BSE curriculum has four main topics that encompass the subject matter knowledge: business environments, business operations, business roles and business ventures. These topics are linked to the comprehension and critical thinking on specific business 
activities, learning objectives and teaching strategies. Four broad types of knowledge as stipulated in MRTEQ are relevant to this research because they are applicable to preservice teaching (student-teachers). Moreover, they are also relevant to in-service teachers (practising teachers), who are in continuous interaction with the four types of knowledge:

- disciplinary knowledge: disciplinary or subject matter knowledge

- situational knowledge: situations, contexts, environments of education

- practical knowledge: teaching practice

- pedagogical knowledge: how to teach - curriculum, assessment, learners. ${ }^{6}$

The inter-relatedness of the four themes is particularly evident in the acquisition of specialised knowledge (disciplinary or content knowledge) as argued by Rusznyak, ${ }^{17}$ which Young et al. ${ }^{4}$ referred to as powerful knowledge or reliable knowledge. Young et $\mathrm{al}^{4}{ }^{4}$ aver that powerful knowledge resides within a formal structure where specialised knowledge is not acquired or produced informally or forms part of people's everyday lives. These formal structures include schools and universities where specialised knowledge communities exist with rules, concepts and boundaries. However, not much has been reported on powerful knowledge in BSE curricula, or the locus of concepts within the knowledge structures of the subject.

Thirdly, the pedagogical challenge is to make subject matter content knowledge relevant to students from diverse backgrounds, as stated by Hordern. ${ }^{5}$ Pedagogical approaches and the selection of resource material are pivotal to make the subject content relevant to students. Maistry et al. ${ }^{14}$ argue that the dominant resources for BSE have been adopted from a Western and/or Eurocentric world view in which perceptions revolve around a male, white and liberal view of reality. Fisher ${ }^{7}$ also claims that the challenge for BSE research on pedagogy is that limited research has been undertaken on the theory-practice relationship and the development of skills to create a viable theory-in-practice or praxis.

Fourthly, the lack of status and value in business education, as claimed by Alsagheer et al., ${ }^{12}$ has increasingly been questioned, not only for the attainment of exit-level outcomes, but also for how it is perceived as a field of study. This apparent lack of status emanates from the comparison of science and mathematics competencies as scarce skills. In undergraduate programmes at many education faculties, business education is an elective. America ${ }^{15}$ avers that not many students choose it as their area of specialisation, because they are more likely to get a student bursary from the government if they choose science or mathematics. Moreover, researchers have pointed to a growing gap between the skills needed in the business world and what is being taught in higher education institutions. ${ }^{12,18}$

Fifthly, according to Brant et al., ${ }^{1}$ the academic versus vocational divide influences curriculum development and the credibility of business studies as an academic subject. Business Studies is often criticised as being insufficiently practical as vocational preparation, implied as the vocational or theoretical dichotomy. The complexity of the educational system and the over-reliance on summative assessment for the curriculum outcomes have an impact on the resources needed for practical learning. The school environment is often criticised for the vocation or theory dichotomy in overstressing academic content at the expense of students gaining practical experience. In TE, the practice teaching component forms an integral part of their training. In the case of business education, real-world relevance is more important than ever. ${ }^{11,16,19}$ BSE teachers, with the support of the school management, can create awareness and encourage enterprising behaviour, creativity, skills and competency development. ${ }^{2,20,21,22}$ Unfortunately, not enough research has been conducted on enterprise and business education for initial TE. ${ }^{23}$

The above concerns informed the scope and conceptual framework of this research, which encompasses the four key knowledge areas that focus on subject matter, context (situational), pedagogy and the practical aspects of the teaching and learning process.

\section{Methodology}

A meta-study is applied to interpret and systematically review primary research to reveal the similarities and differences across a range of different studies. ${ }^{24} \mathrm{~A}$ meta-study is different from a traditional literature review in that it is conducted in a methodical (or systematic) and unbiased manner, according to a pre-specified protocol. ${ }^{25}$ Of specific interest in this case was the scope of peer-reviewed research publications about BSE in South Africa between 1994 and 2015 according to four themes: situational knowledge, content knowledge, pedagogical knowledge and practical knowledge. These four themes broadly cover the key aspects identified in the literature review on the challenges in BSE within the South African context.

The analysis process of this meta-study starts with the identification of studies that comply with the pre-specified protocol, followed by the (re)interpretation according to the four themes identified, after which the data are appraised and key findings are summarised. In addition, the reasons for the different results across studies and limitations of current knowledge are presented. ${ }^{26}$ Booth $^{27}$ is of the view that the results of such a systematic review could lead to the development of new knowledge, a synthesis or interpretative conversion of the new knowledge.

We reviewed the protocols employed by Dempster, ${ }^{25}$ Khan et al. ${ }^{28}$ and Moher et al. ${ }^{29}$ For the purposes of this research, the inclusion criteria were the following:

- All studies must be conducted on South Africa.

- Journal article publications that were peer reviewed and published between 1994 and 2015:

- must be accessible to the researchers 
- should include research in BSE or BSE combined with other school subjects

- should focus on practices or aspects (pedagogy, resources, content, curriculum, philosophy, etc.) related to in-service (school-based) and pre-service teaching and learning (TE).

These inclusion criteria formed the basis for the keywords that were used. Each of these keywords was linked with 'South Africa and with advanced search items 'teach*' and 'school*'. The numbers in brackets reveal the number of initial search items for all the databases:

- business education $=4450$

- business studies education $=5065$

- business teacher* $=3057$

- business studies teacher* $=2859$.

Figure $1^{29}$ shows a flow diagram of the different screening stages. The reason why the initial search was so high (15 431) is because 'business' and 'school' also appeared as 'business school' referring in most cases to research related to courses such as a Master in Business Administration offered at a business school. With the assistance of the university's librarian, the databases included in this research were Scopus, EBSCO (the EBSCO collections included Academic Search Premier, Africa-Wide Information, Business Source Premier, MasterFILE Premier and Teacher Reference Center), Emerald, Nexus and SAePublications.

The next step was to remove all the duplicates, search for title and content relevance of the abstracts, which produced a total of 57 articles. We then screened the articles for relevance

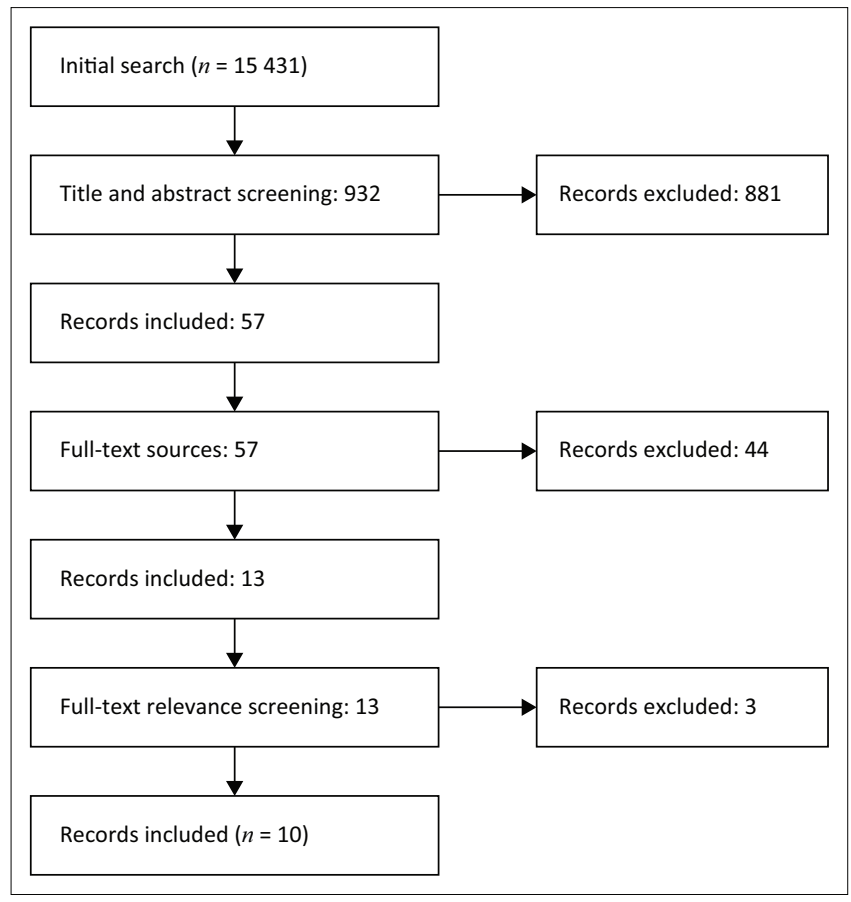

Source: Adapted from Moher D, Liberati A, Tetzlaff J, Altman D, The PRISMA Group. Preferred reporting items for systematic reviews and meta-analyses: The PRISMA statement [flow diagram]. PLoS Med. 2009a;6(7):877. https://doi.org/10.1371/journal.pmed1000097

FIGURE 1: Summary of screening stages. ${ }^{29}$ at the full-text level, and in the process 44 were excluded, thus leaving us with 13 articles. However, three articles had a (negligible) mention of the teaching of Business Studies, which were therefore excluded, leaving a final number of 10 articles for the study. The predominant focus of the excluded three articles was on societal impact factors in general.

Mendeley and Excel were used as tools to organise and code the results. Mendeley, specifically, was chosen for its suitability for working with published literature (as opposed to a tool such as Atlasti, which is more generic) as well as for its collaborative functionality. All decisions used in compiling the information were explicit, reducing potential bias and ensuring the quality of the review process.

The 10 documents included were coded at the first level into two main categories: (1) TE, which included articles about pre-service student-teachers doing Business Studies as a specialisation subject, which reflect research conducted within but not exclusive to an education faculty; and (2) research related to SL Business Studies and in-service teacher development.

The articles about business management undergraduate courses and academic performance or academic development were removed from the final data set, unless they dealt with TE and business studies at SL.

The aim of this meta-study was to give an overview of the focal points of the publications to establish the trends and future directions for BSE in South Africa. The final 10 articles had been published in six journals. Dissertations are excluded, as many could not be sourced full text. Table 1 summarises the analysis, followed by a discussion based on, and in some instances a combination of, the aspects of disciplinary, situational, practical and pedagogical knowledge.

Table 1 highlights the various gaps in the respective themes. The structure of the table was adapted from the outline used in the research of Rusznyak ${ }^{17}$ and Minnaar ${ }^{24}$ and focused attention on the sub-themes within the four broad types of knowledge.

\section{Results and discussion}

The gaps in BSE disciplinary knowledge relate to its theoretical foundations based on philosophy, psychology, politics, sociology, historical perspectives, professional ethics and relationships and the economics of education. Many of these gaps signify the need for BSE to be conceptualised at a much broader socio-economic and even political level. These are areas for research which could foster a developmental and transformative way of thinking about BSE. Another limitation is reflective practice inquiries, such as self-study methodology. Self-study broadly refers to a study based on a teacher educator's reflection of his or her own practice, experience and action for reflection and has become more prevalent since the 1990s..$^{38}$ Using a self-study methodology could be an appropriate avenue to explore ethical and moral issues in BSE. ${ }^{39}$ 
TABLE 1: Summary of results: Business studies education. ${ }^{17,24}$

\begin{tabular}{|c|c|c|}
\hline Four types of knowledge & Knowledge included & Authors $\dagger$ \\
\hline \multirow[t]{2}{*}{ Disciplinary } & Subject matter knowledge & $\begin{array}{l}\text { (1) Meintjes et al. }{ }^{3}[\mathrm{~S}] \\
\text { (2) Gouws and Russell }{ }^{30}[\mathrm{~S}] \\
\text { (5) Burger et al. }{ }^{31}[\mathrm{~S}] \\
\text { (6) Isaacs et al.32 } \\
\text { (10) America }{ }^{15}[\mathrm{TE}]\end{array}$ \\
\hline & $\begin{array}{l}\text { Education and its theoretical } \\
\text { foundations: } \\
\text { - Philosophy of education } \\
\text { - Psychology of education } \\
\text { - Politics of education } \\
\text { - Sociology of education } \\
\text { - Economics of education } \\
\text { - History of education } \\
\text { - Professional ethics } \\
\text { - Professional relationships }\end{array}$ & - \\
\hline \multirow[t]{2}{*}{ Situational } & $\begin{array}{l}\text { Learning situations, } \\
\text { contexts, environments }\end{array}$ & $\begin{array}{l}\text { (6) Isaacs et al. }{ }^{32}[\mathrm{~S}] \\
\text { (7) Kroon et al. }{ }^{33}[\mathrm{~S}]\end{array}$ \\
\hline & $\begin{array}{l}\text { Prevailing policy, political, } \\
\text { organisational contexts }\end{array}$ & $\begin{array}{l}\text { (6) Isaacs et al.32 [S] } \\
\text { (8) North } \text { No }^{34}[\mathrm{~S}]\end{array}$ \\
\hline \multirow[t]{2}{*}{ Practical } & $\begin{array}{l}\text { Learning from practice: } \\
\text { - Craft knowledge from } \\
\text { observing and reflecting }\end{array}$ & - \\
\hline & $\begin{array}{l}\text { Learning in practice: } \\
\text { - Tacit knowledge from } \\
\text { preparing, teaching, } \\
\text { reflecting }\end{array}$ & (8) North ${ }^{34}[\mathrm{TE}]$ \\
\hline \multirow[t]{7}{*}{ Pedagogical } & $\begin{array}{l}\text { Pedagogical content } \\
\text { knowledge }\end{array}$ & $\begin{array}{l}\text { (2) Gouws and Russell }{ }^{30}[\mathrm{~S}] \\
(10)^{15}[\mathrm{TE}]\end{array}$ \\
\hline & $\begin{array}{l}\text { Inclusive education } \\
\text { (diversity, disabilities, etc.) }\end{array}$ & - \\
\hline & $\begin{array}{l}\text { General pedagogical } \\
\text { knowledge: } \\
\text { - Learners (profiles, } \\
\text { performance, under- and } \\
\text { over-achievers, attitudes, } \\
\text { etc.) }\end{array}$ & $\begin{array}{l}\text { (1) Meintjes et al. }{ }^{3}[\mathrm{~S}] \\
\text { (5) Burger et al. } .^{31}[\mathrm{~S}] \\
\text { (6) Isaacs et al. }{ }^{32}[\mathrm{~S}]\end{array}$ \\
\hline & $\begin{array}{l}\text { - Learning (how learning } \\
\text { takes place, enhancement, } \\
\text { alternative forms, } \\
\text { intervention strategies, } \\
\text { teaching resources, } \\
\text { e-learning, etc.) }\end{array}$ & $\begin{array}{l}\text { (1) Meintjes et al. }{ }^{3}[\mathrm{~S}] \\
\text { (3) Maistry and Pillay } \\
\text { (4) Govender and } \\
\text { Maistry }{ }^{36}[\mathrm{~S}] \\
\text { (8) North }{ }^{34}[\mathrm{~S}] \\
\text { (9) Mtshali et al. }{ }^{37}[\mathrm{TE}]\end{array}$ \\
\hline & $\begin{array}{l}\text { - Curriculum (shifts in } \\
\text { curriculum, curriculum } \\
\text { development, inquiry, etc.) }\end{array}$ & - \\
\hline & $\begin{array}{l}\text { - General instructional } \\
\text { strategies and approaches }\end{array}$ & $\begin{array}{l}\text { (1) Meintjes et al. } .^{3}[\mathrm{~S}] \\
\text { (4) Govender and } \\
\text { Maistry }^{36}[\mathrm{~S}]\end{array}$ \\
\hline & - Assessment strategies & (2) Gouws and Russell ${ }^{30}[\mathrm{~S}]$ \\
\hline
\end{tabular}

Source: Adapted from Rusznyak L. Knowledge selection in initial teacher education programmes and its implications for curricular coherence. J Educ. 2015;60:7-20. https://doi. org/10.17159/i60a01, and Minnaar A. Student support in e-learning courses in higher education-insights from a metasynthesis - A pedagogy of panic attacks. Afr Educ Rev. 2011;8(3):483-503. https://doi.org/10.1080/18146627.2011.618664

Note: Please see the full reference list of the article, America C, Skelly L. 2021, Exploring the scope of and gaps in the teaching and learning of Business Studies at school and teacher scope of and gaps in the transdiscipl res S Afr. 2021:17(1), a1040. https://doi.org/10.4102/td.

$\mathrm{TE}$, teacher education; $\mathrm{S}$, school.

$\dagger$, Research focusing on teacher education or school levels.

The gaps in terms of pedagogy reflect issues of inclusivity and curriculum inquiry. ${ }^{13}$ America and Le Grange ${ }^{13}$ claim that teacher educators of BSE are often criticised for not being critical enough about the formal curriculum to mediate learning that raises questions about the conduct and decision-making of corporate businesses. Moreover, this gap could also sensitise researchers towards the decolonisation of the BSE curriculum, because there is a silence in the selected articles in this regard. For example, an important resource in BSE is business case studies, which are mostly written from a Western and/or Eurocentric world view with a neoclassical ideological bias mostly devoid of local (South) African realities. Over the years, business studies educators became dependent on these knowledge systems, epistemological traditions and curriculum materials.
In all the articles, only the specific focus on Business Studies was considered and the scope of the analysis was confined to the following four themes discussed as the conceptual framework earlier: disciplinary, situational, practical and pedagogical knowledge.

\section{Disciplinary knowledge}

Entrepreneurship is highlighted in the research by Gouws et al..$^{30}$ and Meintjies et al. ${ }^{3}$ as important content within the school context. They apply intervention strategies to reinforce the relevance of entrepreneurship in BSE through powerful knowledge and key threshold concepts integrated with the vocational element. Burger et al. ${ }^{31}$ examined the impact of the business-related knowledge (formal and informal) of grade 12 learners on their entrepreneurial attitudes. Formal education here referred to business-related education at SL. Informal education referred to their practical experiences and skills acquired because of part-time work in business environments as well as previous exposure to entrepreneurial role models. They present the findings of learners who have either Economics, Business Studies and/or Accounting as school subjects as well as a non-curriculum subject, entrepreneurship. Isaacs et al. ${ }^{32}$ assessed the levels of entrepreneurship education at the FET level by looking at policy, practice and the context within entrepreneurship education. They argue for education for entrepreneurship as opposed to education about entrepreneurship. They found that there is a need for schools to specialise in entrepreneurship education and training, for opportunities to be created and for resources made available to stimulate and facilitate such initiatives. ${ }^{15}$

\section{Pedagogical knowledge}

Pedagogical content knowledge refers to knowledge about the curriculum and pedagogy. How to teach aspects of the curriculum, learners and/or assessment form part of this category. Meintjies et al. ${ }^{3}$ presented practical exposure in a simulated business environment through active learning. Their goal was to enrich the curriculum through the enhancement of entrepreneurial competencies and to develop problem-solving capabilities. Gouws and Russell ${ }^{30}$ proposed shifts in the curriculum from the outcomes-based assessment of learning to assessment for learning by means of a 3-year project-based practical intervention for grade 12 learners. Their first project was based on selecting and designing appropriate teaching resources and the second one was a project on environmentalism and sustainable consumerism. Apart from the learners' involvement in addressing real social problems as part of their project, the Business Studies teacher, who was the project mentor, was also interviewed. The authors ${ }^{30}$ proposition is for learners to develop the skills to do research and to have proper scientific research principles as part of the curriculum, whilst students are addressing the real social problems as part of the project.

Textbooks are key teaching and learning resources, which should transmit and control knowledge within the boundaries and values of the Constitution. However, not all 
textbooks comply with these values, as seen in the way that Maistry et al. ${ }^{35}$ explored the gendered characteristics in their analysis of two Business Studies textbooks. If teachers use this textbook uncritically, it may reinforce the specific values and ideologies of the authors or serve as a mouthpiece for a specific political allegiance. Their findings suggest that textbooks continue to reinforce gender bias. The suggestion is that curriculum material in schools should be selected carefully to ensure that gender equality is included in resources. In the context of accounting at SL, Ngwenya et al..$^{40}$ cautioned that teachers must be circumspect about in their use of and over-reliance on textbooks, even though textbooks play a pivotal role in providing structure, support and guidance to the learners.

Insights into the views of teachers of business education (including Accounting, Economics and Business Studies) on the adoption of Information and Communication Technology (ICT) in the classroom are put forward by Govender et al. ${ }^{36}$ They argued that because of the ubiquitous nature of technology initiatives across the world, the perceived usefulness and relative advantage for ICT pedagogy must be considered. Whilst BSE teachers are, in general, positive about the compatibility of ICT with their current teaching practices, they also cautioned that time constraints and facilitating conditions are not always conducive to such innovativeness.

As discussed by Mtshali et al., ${ }^{37}$ Business Studies studentteachers' experience of and reaction to the use of online chats as part of the course offering enables students to comment on new work as they progress with curriculum content. This means that collaboration is enhanced as they share curriculum content and their views. North ${ }^{34}$ provided an account of curriculum renewal leading up to the implementation of Curriculum 2005 and beyond where learners, teachers and the private sector were engaged in entrepreneurial programmes. ${ }^{15}$ Findings suggest that by introducing deliberate and consistent practices, students can become critically aware of and confident in interrogating disciplinary content in business.

\section{Practical knowledge}

This theme focuses on the practical aspect of teacher training and professional development for in-service teachers. North ${ }^{34}$ provided a comprehensive background to the introduction of entrepreneurship education and the training of teachers in entrepreneurship programmes in schools during a curriculum renewal process in 1994 and later as part of Curriculum 2005. The research focused on the entrepreneurship initiatives that were undertaken by roleplayers in the private sector and curriculum developers.

\section{Situational knowledge}

As argued by Kroon et al., ${ }^{33}$ the role and perceptions of business people and entrepreneurial learnership programmes at schools have increased the skills requirements of the workplace drastically and this may have outstripped the education system's capacity to provide the needed skills effectively. They found that most business employers do not believe that schools provide the necessary skills needed for the business world. To address this skills gap, they recommend a structured youth entrepreneurial learnership programme at SL. North ${ }^{34}$ gives an account of entrepreneurship initiatives by various role-players in the private sector and education sectors. He describes the historical background of entrepreneurship education, informal training of in-service teachers and the perspectives of learners about the relevance of entrepreneurship education in the school curriculum.

The above discussion illustrates the current scope of BSE research as well as the gaps in the literature. Mostly qualitative studies were conducted with interviews and observations as data collection methods. Gouws et al..$^{30}$ used a case study design to gain greater insight into the dynamics of assessment for learning. Maistry et al. ${ }^{35}$ applied critical discourse analyses to evaluate the textbooks through open coding, analysing sentences, phrases and words focusing on the insinuations, tone and the language that imply power relations. Isaacs et al. ${ }^{32}$ used telephonic interviews consisting of questions related to the state, challenges and opportunities for improvement of entrepreneurship education at schools. Mtshali et al. ${ }^{37}$ preferred personal reflective journals, focus group discussions, individual interviews and a quantitative component by means of a questionnaire. They applied a phenomenological approach to unveil what the studentteachers' experiences of learning are by using online chats to serve as knowledge repositories that can enhance greater student engagement with learning. ${ }^{15}$ Quantitative approaches by Govender et al., ${ }^{36}$ Burger et al. ${ }^{31}$ and Kroon et al. ${ }^{33}$ were applied by means of question-based scenarios using descriptive and exploratory approaches to analyse the data.

As with most research, this research has also some limitations. Even though we used a wide selection of databases, and with the assistance of the research librarian, there is a possibility that some publications could not be 'picked up' by the searches. Another limitation is that a specific time frame had to be established beforehand to allow enough time for the searches, cross-checking, organising and analysis of the data. There may have been other publications after 2015 which could have addressed some of the gaps identified. We acknowledge that different criteria could have led to different conclusions; however, we deemed the four knowledge factors we applied, namely, disciplinary, situational, practical and pedagogical knowledge, as most appropriate for our objectives. We also localised the research only to a South African context, which may not be generalisable to other contexts. More research is needed to identify other challenges within the school and TE context for Business Studies.

\section{Conclusion}

The relevance of BSE in school curriculum is undisputed, yet this review shows that there are gaps in the scope of research 
conducted on BSE from 1994 to 2015. The gaps that need to be addressed include the need for disciplinary knowledge to be evaluated much more broadly, for example, the philosophical foundations, socio-economic and political imperatives within the discipline, a historical overview and ethical and professional relationships. There is also a gap in terms of reflective practices when it comes to practical knowledge. In pedagogy, the gaps had to do with issues of inclusivity and curriculum inquiry. Entrepreneurship appears to be a common and important focal point in the research under the disciplinary knowledge theme, all four studies were conducted at SL. This clearly reflects the importance that researchers attach to cultivating entrepreneurial knowledge and skills from a young age and even to the need for gaining practical experience and exposure as part of curriculum outcomes. Other similarities emerged about situational knowledge and the school environment about the linkages between the education system, private sector requirements and informal sector skills requirements. Most of the research conducted on pedagogical knowledge was at the SL, with most studies focusing on how learning takes place, alternative forms, teaching resources and (e-)learning interventions.

This meta-study devoted attention to content knowledge, situational knowledge, practical knowledge and pedagogical knowledge within a TE and an SL context. The upshot of this synthesis is the identification of promising areas for new research initiatives and continuous contestation of BSE knowledge through publication output. The following are some of the areas of research that could be further explored. Firstly, the apartheid legacy still has repercussions in the socio-economic environment in which the learners (and teachers) find themselves, such as poverty and inequality, high unemployment, child-headed households, crime and illiteracy amongst parents - all of which have a negative impact on the South African school system. A developmental and transformative conceptualisation of BSE within the current educational landscape could be therefore explored. Secondly, self-study methodology is gaining traction in TE research. As part of the practical knowledge theme, selfstudy inquiry could be encouraged in BSE to promote reflective practice. Thirdly, TE and training (in)directly impact the school system. More research is needed to encourage critical thinking at the TE level, for example, to encourage in-service teachers to critique curriculum policy, be circumspect about their selection of teaching and learning resources and to develop sensitivities to curriculum debates such the decolonisation of the curriculum. Another aspect for further research is the philosophical grounding of BSE disciplinary knowledge, the needs of society and the shifts in curriculum policy, development and design.

\section{Acknowledgements}

The financial assistance of the National Research Foundation (NRF) towards this research is greatly acknowledged. Opinions expressed and conclusions arrived at are those of the authors and need not necessarily be attributed to the NRF.

\section{Competing interest}

The authors declare that no competing interest exists.

\section{Authors' contributions}

C.A. conceptualised the study, analysed the data and wrote the first draft. L.S. outlined and researched the methodology and facilitated critical review. Both authors read and approved the final version of the manuscript.

\section{Ethical considerations}

This article followed all ethical standards for research.

\section{Funding information}

Funding for this study was granted by the National Research Foundation (Grant No: BM_TTK160904187409).

\section{Data availability}

The data that support the findings of this study are available from the corresponding author, C.A., upon reasonable request.

\section{Disclaimer}

The views and opinions expressed in this article are those of the authors and do not necessarily reflect the official policy or position of any affiliated agency of the authors.

\section{References}

1. Brant J, Cullimore D. Participation, progression and value added: Business and economics for 14-19-year-olds in England. Curric J. 2012;23(1):79-98. https:// doi.org/10.1080/09585176.2012.650488

2. Birdthistle N, Hynes B, Fleming P. Enterprise education programmes in secondary schools in Ireland: A multi-stakeholder perspective. Educ Train. 2007;49(4):265276. https://doi.org/10.1108/00400910710754426

3. Meintjes A, Henrico A, Kroon J. Teaching problem solving competency in Business Studies at secondary school level. S Afr J Educ. 2015;35(3):1-11. https://doi. org/10.15700/saje.v35n3a1102

4. Young $M$, Muller J. On the powers of powerful knowledge. Rev Educ. 2013;1(3):229-250. https://doi.org/10.1002/rev3.3017

5. Hordern J. Is powerful educational knowledge possible? Cambridge J Educ. 2018;48(6):787-802. https://doi.org/10.1080/0305764X.2018.1427218

6. Department of Higher Education and Training (DHET). National Qualifications Framework Act 67 of 2008. Policy on the minimum requirements for teacher education qualifications. Pretoria, South Africa. Government Gazette. 2011;34467(583):1-64

7. Fisher R. The golden age of BTEC: The business education curriculum in 1980 s further education. Curric J. 2003;14(2):253-277. https://doi. org/10.1080/09585170302835

8. Stronach I. Education, vocationalism and economic recovery: The case against witchcraft. $\mathrm{Br} J$ Educ Work. 1989;3(1):5-31. https://doi. org/10.1080/0269000890030101

9. Department of Basic Education. Curriculum and assessment policy statement grades 10-12: Business studies. Pretoria: Government Press; 2011.

10. Umalusi. What's in the CAPS package? Business, Commerce \& Management. Council for Quality Assurance in General and Further Education and Training. Pretoria: Umalusi Press; 2014

11. America C, Mallon P. 'Connectedness' in Business Studies pedagogy: Is a transition year alluring? Perspect Educ. 2020;38(2):70-85.

12. Alsagheer A, Alsagheer $\mathrm{S}$. The role of business education at the $\mathrm{K}-12$ level: Faculty perceptions on establishing a business education department in the college of basic education at the public authority for applied education and training. Int Bus Econ Res J. 2010;9(11):5-16. https://doi.org/10.19030/iber. v9i11.25

13. America C, Le Grange L. Dekolonisering van die kurrikulum: 'n kontekstualisering van Ekonomie- en Besigheidstudieonderrig/Decolonising the curriculum: contextualisting Economics and Business Studies teaching. Tydskr. geesteswet. 2019;59(1):106-123. https://doi.org/10.17159/2224-7912/2019/v59n1a7 
14. Maistry SM, David R. The school economics textbook as programmatic curriculum: An exploited conduit for the neoliberal globalisation discourses. J Educ. 2018;74:32-46. https://doi.org/10.17159/2520-9868/i74a03

15. America, C. Integrating literacy practices in Business Education: Pedagogical intentions for teacher training. Per Linguam. 2014;30(3):16-25.

16. America, C. Integrating sustainability into Business Education teacher training. $S$ Afr J Educ. 2014;34(3):1-8.

17. Rusznyak L. Knowledge selection in initial teacher education programmes and its implications for curricular coherence. J Educ. 2015;60:7-20. https://doi. org/10.17159/i60a01

18. Mohamed EK, Lashine SH. Accounting knowledge and skills and the challenges of a global business environment. Manag Finance. 2003;29(7):3-16. https://doi. org/10.1108/03074350310768319

19. Skipton $M$, Cooper T. Teaching and learning for real-world relevance in management education - Developing a model. J High Educ Theor Pract. 2012;12(6):26-39.

20. Leffler E, Näsström G. Entrepreneurial learning and school improvement: A Swedish case. Int J Hum Soc Sci Educ. 2014;1(11): 243-254.

21. Matlay $\mathrm{H}$. The influence of stakeholders on developing enterprising graduates in UK HEls. Int J Entrep Behav Res. 2011;17(2):166-182. https://doi. org/10.1108/13552551111114923

22. Ruskovaara E, Pihkala T. Teachers implementing entrepreneurship education: Classroom practices. Educ Train. 2013:55(2):204-216. https://doi. org/10.1108/00400911311304832

23. Tiernan P. Enterprise education in initial teacher education in Ireland. Educ Train 2016;58(7/8):849-860. https://doi.org/10.1108/ET-03-2016-0053

24. Minnaar A. Student support in e-learning courses in higher education-insights from a metasynthesis - A pedagogy of panic attacks. Afr Educ Rev. 2011;8(3):483-503. https://doi.org/10.1080/18146627.2011.618664

25. Dempster M. Systematic review. In Miller R, Brewer J, editors. The A-Z of socia research. London: Sage, 2003; p. 312-316. https://doi.org/10.4135/978085 7020024

26. Garg AX, Hackam D, Tonelli M. Systematic review and meta-analysis: When one study is just not enough. Clin J Am Soc Nephrol. 2008;(1):253-260. https://doi. org/10.2215/CJN.01430307
27. Booth A. Brimful of Starlite: Toward standards for reporting literature searches. J Med Library Assoc. 2006;94(4):421-205.

28. Khan KS, Kunz R, Kleijnen J, Antes G. Five steps to conducting a systematic review. J R Soc Med. 2003;96(3):118-121. https://doi.org/10.1258/jrsm.96.3.118

29. Moher D, Liberati A, Tetzlaff J, Altman D, The PRISMA Group. Preferred reporting items for systematic reviews and meta-analyses: The PRISMA statement [flow diagram]. PLoS Med. 2009a;6(7):e1000097. https://doi.org/10.1371/journal. pmed1000097

30. Gouws E, Russell Y. Assessment for learning: A case study in the subject business studies. J New Gener Sci. 2013;11(1):74-88.

31. Burger $L, O^{\prime}$ Neill $C$, Mahadea D. The impact of previous knowledge and experience on the entrepreneurial attitudes of Grade 12 learners. S Afr J Educ. 2005;25(2):89-94.

32. Isaacs E, Visser K, Friedrich C, Brijlal P. Entrepreneurship education and training at the Further Education and Training (FET) level in South Africa. S Afr J Educ. 2007;27(4):613-630.

33. Kroon J, De Klerk S, Dippenaar A. Developing the next generation of potential entrepreneurs: Co-operation between schools and businesses? S Afr J Educ. 2003;23(4):319-322.

34. North E. A decade of entrepreneurship education in South Africa. S Afr J Educ 2002;22(1):24-27.

35. Maistry SM, Pillay P. Gender representation in contemporary grade 10 business studies textbooks in South Africa. Perspect Educ. 2014;32(4):74-92.

36. Govender DW, Maistry SM. Exploring teachers' propensity for technology adoption in business education. J Soc Sci. 2012;31(2):193-202. https://doi.org/10 .1080/09718923.2012.11893028

37. Mtshali MA, Maistry SM, Govender DW. Online chats: A strategy to enhance learning in large classes. S Afr J Educ. 2015;35(4):1-9.

38. Zeichner K. Accumulating knowledge across self-studies in teacher education J Teach Educ. 2007;58(1):36-46. https://doi.org/10.1177/0022487106296219

39. America C. Teaching business ethics to pre-service teachers: An integrated approach. In C America, N Edwards, M Robinson (Eds), Teacher education for transformative agency - Critical perspectives on design, content and pedagogy. Sun Press, Stellenbosch. 2020:125-140.

40. Ngwena J, Arek-Bawa O. Exploring the quality of Grade 12 accounting education textbooks. J Trans Res S Afr. 2019;15(1):a662.https://doi.org/10.4102/td.v15i1.662 